\section{The Role of the Digital Terrain Models in the Assessment of Surplus Water Risk at the Szolnok-Túri Plain}

\author{
Károly Tóth - János Tamás - Tibor Bíró \\ University of Debrecen, Centre for Agricultural Sciences, \\ Faculty of Agricultural Sciences, \\ Department of Water and Environmental Management, Debrecen \\ ktoth@gisserver1.date.hu
}

\section{SUMMARY}

The environmental factors to which surplus water can be assigned (topography, soil, groundwater, vegetation etc.) can be subject to special analysis and the randomness of the occurrences can be limited. The results of these procedures are surplus water risk maps of the areas, which can be utilised in land use planning. The risk map of the research site was created with overlaying digital category maps of the determining factors (hydraulic conductivity, convexity, critical probability of ground water level and land use).

Keywords: GIS, topography analysis, surplus water risk, hydraulic conductivity

\section{INTRODUCTION}

The Szolnok-Túri Plain is a territory possessing conditions characteristic of plains, with a slope under $2 \%$, so the occurrence of surplus water is frequent in this area. As a consequence of these facts, the region is among the most endangered sub-catchment areas of both the Great Hungarian Plain and of the country. That No. 10.08 surplus water-control section belongs to the lathe of Karcag, with a territory of $423 \mathrm{sq} \mathrm{kms}$.

Extreme climatic conditions are characteristic of the area. These extremities usually manifest in the seasonal diversity of rainfall, and in the changeable regional and temporal dispersion of rain. These cause serious problems especially in agriculture.

One of the unfavourable effects of climatic extremities can be the harmful increase in the water supply of the plains which can lead to the formation of aboveground water levels, or so-called surplus water spots. The possibilities of moderating direct and indirect damage caused by surplus water lie in prevention and in the quick and proper diverting of the assembled surplus water (Petrasovits, 1982; Vajdai, 1981).

The main factors affecting surplus water formation on the plains are the geographical features of the surface. The flow of surface waters is limited because of the small slope of the land, so they gather in the local deep areas. In these regions the occurrence of extensive and persistent surface overlays are more frequent (Pálfai, 1994).

Prevention always has to be based on the exact and detailed knowledge of the hydrological, meteorological and soil conditions of the area. The spread of GIS made the fight against surplus water easier. The modern methods of data collection (aerial photography, satellite images, remote sensing), the new kinds of data management and data processing
(GIS softwares) make possible a more detailed and more efficient investigation of the problems (Bíró et al., 2002). The new ways of processing can significantly increase the value of the data.

\section{MATTER AND METHOD}

The area itself is the alluvium of the River Tisza. The main formative factor in the region is water. The territory is divided by deep beds without outflow, and as a consequence, the presence of high water level runoff-drains is frequent. In critical periods, even rills with a water level above the ground are characteristic.

\subsection{Soil conditions}

In the past few decades, significant land drainage works took place, and these considerably changed the course of natural soil formation. With the drainage of moors, vast areas became arid, and most of these are under agricultural cultivation now. Soil formation changed positively, towards the formation of meadow soil, meadow chernozem and chernozem. Salinization processes could not be stopped everywhere.

\subsection{Mapping the hydraulic conductivity}

One of the most important factors causing surplus water is the bad permeation of soils (Petrasovits, 1982). After the impregnation of the soil area above the watertight layer, rainfall in the region causes surplus water, because it has no way to flow away. The cessation of surplus water now depends on evaporation and slow infiltration. The existent surface water layer brings about a two-phase soil condition as far as the mildly pervious layer (Oroszlány, 1981). The rate of infiltration in these cases is influenced by the hydraulic conductivity (k) of that stratum (Várallyay, 1976). A map of the investigated area was available, delineating the mechanical composition of soils. On the basis of this, we designed a map depicting the hydraulic conductivity in the area.

It can be pointed out from the infiltration measures that the factor on $50 \%$ of the area is $\mathrm{k}=0,01-0,1 \mathrm{~cm}$ a day, while on the other $50 \%$ it is $\mathrm{k}=3-7 \mathrm{~cm}$ a day. The former means that the soil has very poor permeation conditions, it is considerably watertight. Taking this into account, the probability of surplus water formation is rather high. 


\subsection{Mapping land usage}

During the research, land usage is the parameter hardest to percept. It is relatively permanent in space and time, but on the other hand it is constantly changing.

With the use of the surplus water risk map while planning land usage, those unpleasant situations (surplus water damages) could be avoided that are left out of consideration by the planners, usually during longer dry periods. The maps are useful when changing cultivation processes, and even when marking areas meant to be withdrawn from cultivation. The categories included in the research are the following: crop, tillage, meadow, fishpond and other.

The formation of surplus water is brought forth by permanent and variable factors. The constant aspects are: climatic conditions, configuration of the terrain, soil features, subsoil water situation, water management and the mode of land usage. The changing features are: rainfall, temperature, evaporation, wind, human intervention-agricultural engineering. These factors, however, do not influence surplus water floods in the same manner.

\section{RESEARCH RESULTS AND THEIR ASSESSMENT}

\subsection{D elevation- and digital terrain model of the research area}

One of the primary conditions for the occurrence of surplus water is the presence of areas without runoff (Zsigrai, 2002). If the surface is even, and with a one-way slope, it is not regular that surplus water occurs in areas with unfavourable water management conditions. The configuration of the area has to be examined if the aim is to form a proper notion of surplus water sensitivity.

The altitude numbers of the area are between
81,7-97,9 mBf. The terrain model was designed with the elevation values of topographic maps on the scale of 1:10000. As in our case we used values of elevation points for the design, we had to ignore the 'Kun mounds' characteristic of the region, because they would have made the terrain unreliable. As a consequence, the altitude numbers are between 81,7$91,8 \mathrm{mBf}$. On the basis of the topographic maps we produced a map showing the dispersion of elevation values in the region, as well as a Voronoi map, a trend function, a histogram and a normal distribution function.

\subsection{Research of run-offs}

The terrain determines the direction of elemental surface run-offs in the area, the run-off points, as well as revealing - through the surface watersheds the extent of areas without run-off.

For the definition of areas with no run-off, and for the indication of the run-off points it is necessary to know the directions of run-offs. The starting point for these tasks is the detailed digital terrain model of the region.

We performed the interpolation of the elevation data with kriging. The interpolation was fitted into a 100x100 m resolution grid. Dividing the region into a limited number of parts, it is possible to determine the direction of slopes in each area, pointing horizontally in 360 degrees ( $x-y)$, vertically from 0 to 90 degrees $(\mathrm{x}-\mathrm{z})$. The cells of the three-dimensional grid are characterized by average slopes. This means that there exists a main slope direction which dominantly determines the flow of water in the region.

Visualization of slope directions in the whole $61 / \mathrm{a}$ and $61 / \mathrm{b}$ surplus water system can be seen in Figure 1. The arrows in the figure show the directions of run-offs. It can be seen that there are areas without run-off in the region which provide the terrain conditions for surplus water assembling.

Figure 1: 3D digital terrain model of the research area, with run-off directions

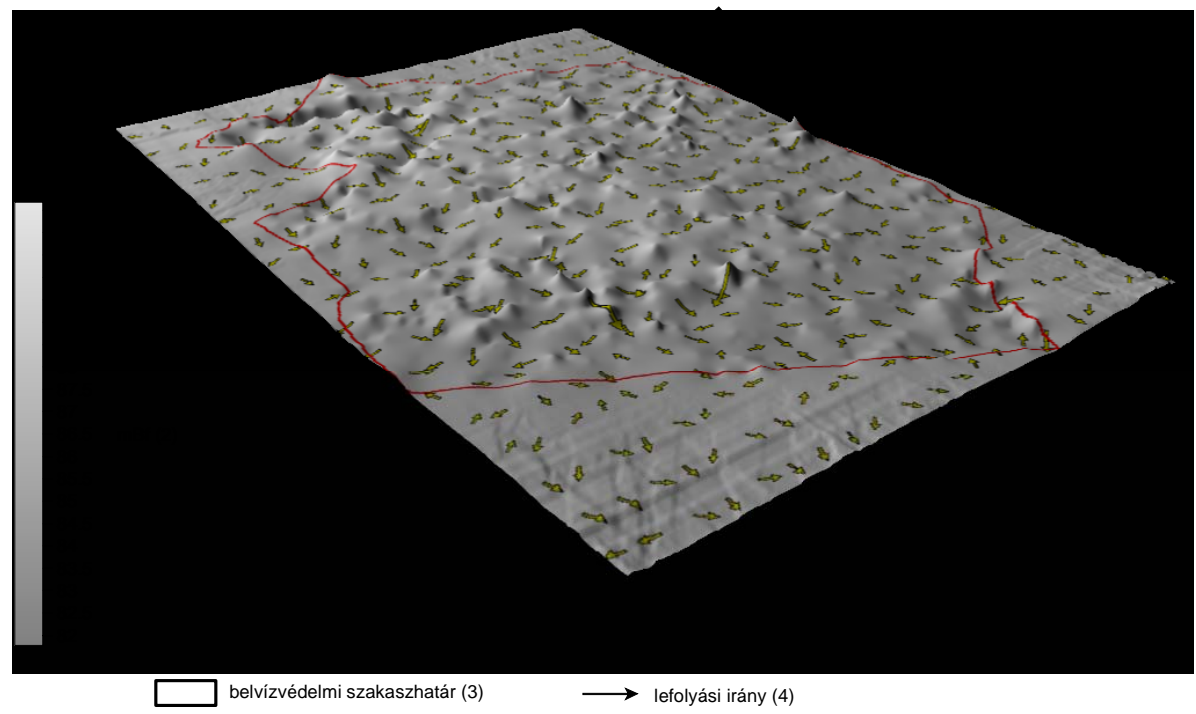

$\mathrm{EOV}(1), \mathrm{mBf}(2)$, boundary of surplus water control section(3), direction of run-off(4) 


\subsection{Convexity conditions of the research area surface}

The run-off direction values reached after double derivation are the basis of modeling water assemblage. The horizontal change of direction represents the convergence and divergence of runoffs.

One of the sure signs of the increase - meaning not only speed but also closeness to depressions in the area - of run-offs is the growth of convergence. The degree of convexity can be turned into numerical data if the divergence from the original direction angle is expressed in percentage or in absolute value. If the region parts with the same change of direction are matched with isometric lines, the degree of convergence or divergence can be represented.

If the contour-lines of the slope are convex with respect to the direction of run-off, the directions gradually diverge from the top of the deflection, so the flowing water disperses. But if the run-off approaches the natural depressions of the surface, the run-off directions gradually converge. This means that the content of more and more cells is concentrated into each section.

The change of run-off directions describes the accumulation phenomenon precisely, therefore being suited to determine the most probable positions of surplus water occurrence.

Our convexity map of the region is shown in Figure 2. With mapping the convexity, the surplus water risk of a given area can be characterized, from a topographic point of view. On the map of convexity we selected the convergent areas, so the definition of areas with high surplus water risk became easier.

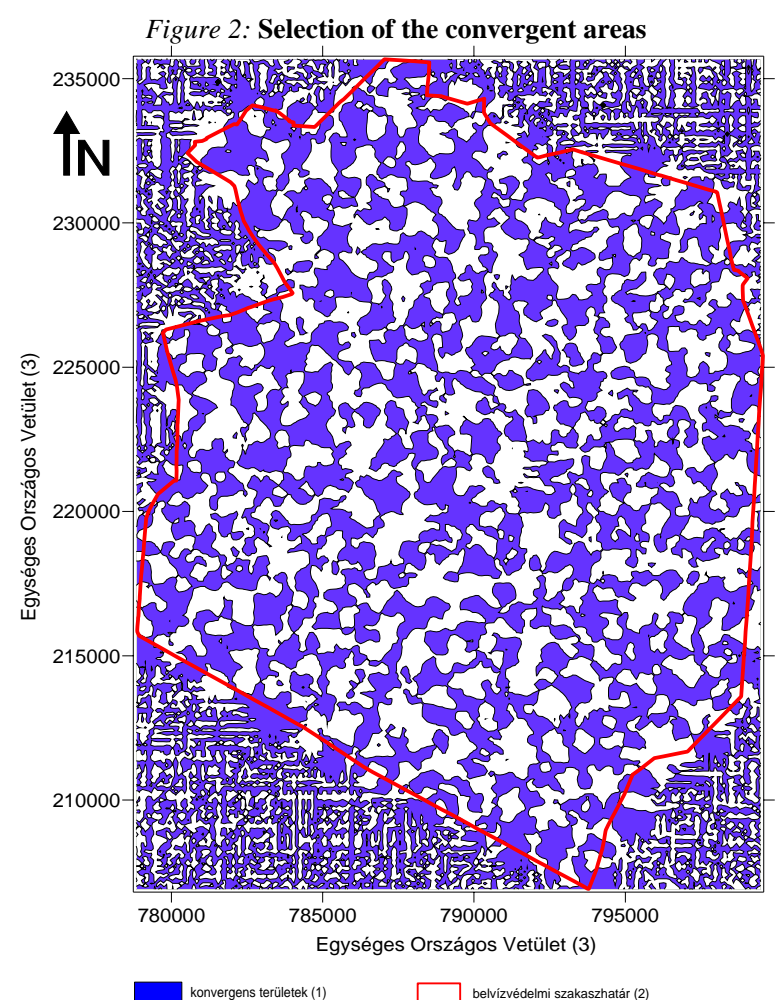

convergent areas(1), boundry of surplus water control section(2), EOV(3)

\subsection{Mapping surplus water risk based upon water logging maps from years between 1940 and 2003}

From the temporal distribution of surplus water it can be concluded that the probability of occurrence is the highest in winter and spring. In summer, the phenomenon is rare, in autumn the possibility of surplus water risk is rather negligible. In the area, control was the most extraordinary in 1999 and 2000, with the largest territories of surplus water.

With the help of the available data, we produced the figure of the maximum surplus water floods (Figure 3), and of the durability of the overflows (Figure 4), for the years 1943-2000.

Figure 3: Maximum surplus water overflow

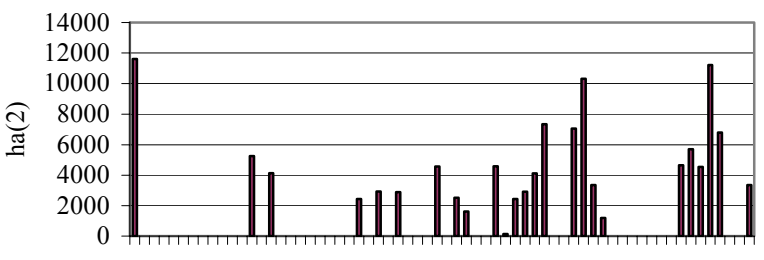

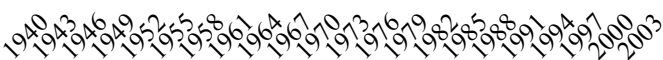

év(1)

years(1), hectares(2)

Figure 4: Durability of floods in days

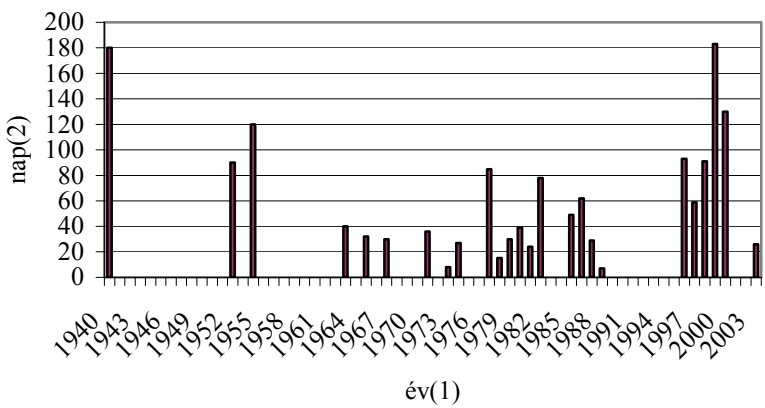

years(1), days(2)

The map of surplus water risk primarily helps with tasks connected to agricultural water management. It can also be an important basis for every development project or control activity going on in those extensive agricultural areas where the intermittent presence of surplus water might cause problems or damage, or where the presence is an advantage. The map can be a great help with the planning of water management in plain regions, as well as with surplus water control, because the required control forces can be concentrated to the most endangered areas in time. It is practical to place irrigation plants to areas with no or little surplus water, and it is also advisable to bear in mind surplus water risks during the selection of irrigation methods and the amount of irrigation water.

With the reclassification of digital maps showing characteristics with relative spatial permanence, category maps can be gained. Overlaying and summarizing these spatially and in succession, a surplus water risk map is produced (Bíró et al., 2002). 
We used all the available overflow maps from the examined period. From those years with two surplus water phases, we considered the bigger floods. We made digital part-maps from the yearly water logging maps, then overlaying these we got a surplus water risk map, shown in Figure 5.

After these, using the relative frequency of the Pálfai-method, we produced cover classes that show the frequency of surplus water areas covering each other. Connected to these, we determined the regions of each risk category. In the end we specified the surplus water risk area measure numbers, with the help of the Pálfai-formula. Using these data, risk $=14,8$. As risk $>12$, the area is fraught with surplus water risk.

Figure 5: Four-category surplus water risk map of section of surplus water control No. 10.08

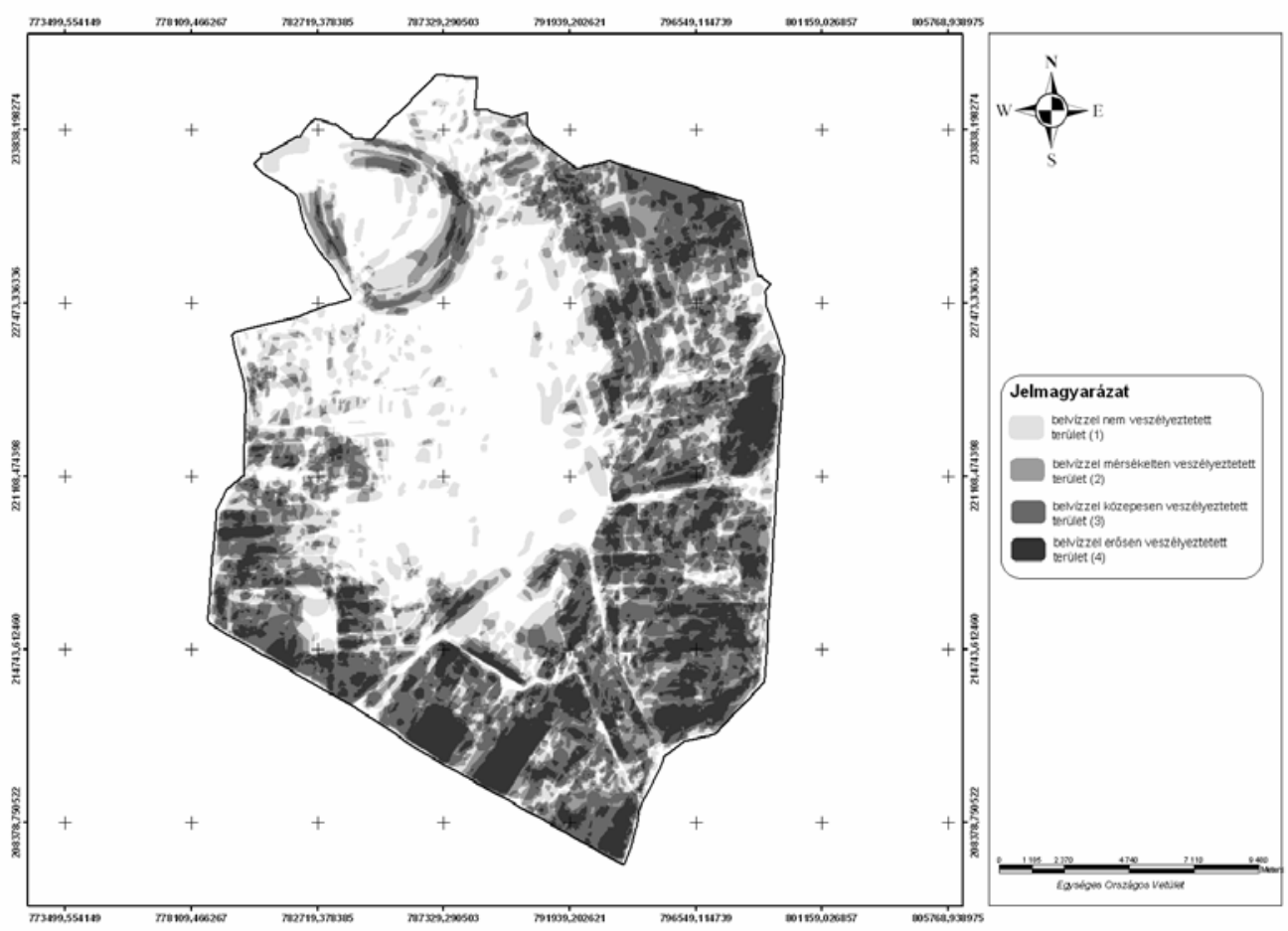

area with no surplus water risk(1), area with moderate surplus water risk(2), area with medium surplus water risk(3), area with high surplus water risk(4)

\section{CONCLUSION}

The determination of risk can only be correct if there are enough data on the research area, at least covering 40 or 50 years.

The genetic terrain map, the hydraulic conductivity of soils, the terrain model and our surplus water risk map are closely connected (bound subgrade, bad hydraulic conductivity, low area, high surplus water risk).

Note that the surplus water sensitive areas cannot be determined with great certainty on the basis of surplus water risk maps, because they do not provide the sufficient amount of data. In other words, to be able to produce a map containing enough data from every field, we need to consider other important factors besides the configuration of the terrain.

During the research we also dealt with the detailed examination of these factors. A risk map might be produced on the basis of one of these factors. From these features we made a genetic soil map, a map showing the hydraulic conductivity and a map showing surplus water risk between 1940 and 2003.
In areas with successive, vast regions of surplus water, a change in cultivation is needed (Pálfai, 1992). Comparing figures containing surplus water risk, topographic data and hydraulic conductivity, the following can be concluded: most of the territories with surplus water risk are tillage areas. This shows that since the beginning of the $1900 \mathrm{~s}$, more than 10.000 hectares of land have been turned from meadow to tillage. This artificial and inefficient interference brings about surplus water risk.

We analyzed how the change in present cultivation modes should be executed.

This area is about $103 \mathrm{sq} \mathrm{kms}$; at least 60 per cent of this would need modification. The proposition is as follows: wood expansion 1. 500 hectare, meadow expansion 3.500 ha, rice field and fish pond expansion 1.000 ha.

Overlaying the surplus water risk map and the terrain model, it can be seen that surplus water is more frequent in low areas.

Our research unambiguously shows that during the analysis of surplus water risk the most important factors are topographic and soil conditions, besides the distribution of rainfall. 


\section{REFERENCES}

Bíró, T.-Tamás, J.-Lénárt, Cs.-Tomor, T. (2002): A belvízveszélyeztetettség térbeli elemzése. Kaposvári Egyetem, Állattudományi Kar, Kaposvár, 6. 3. 139-151.

Oroszlány, I. (1981): Hidrológia. In: Kiss, K.-Oroszlány, I.-Vajdai, I.: Gazdálkodás belvizes területeken. Mezőgazdasági Kiadó, Budapest, 16-52.

Pálfai, I. (1992): Belvízzel veszélyeztetett területek az Alföldön. Környezetgazdálkodási Intézet, Budapest, 83.

Pálfai, I. (1994): Az Alföld belvíz-veszélyeztetettségi térképe. Vízügyi közlemények, LXXVI. 278-290.

Petrasovits, I. (1982): Síkvidéki vízrendezés és gazdálkodás.
Mezőgazdasági Kiadó, Budapest, 332.

Vajdai, I. (1981): A szántóföldi növénytermesztésben okozott károk. In: Kiss, K.-Oroszlány, I.-Vajdai, I.: Gazdálkodás belvizes területeken. Mezőgazdasági Kiadó, Budapest, 80109.

Várallyay, Gy. (1976): Az öntözés néhány talajfizikai vonatkozása. Agrártudományi közlemények, 35. 159-165.

Zsigrai, Gy. (2002): Karcag környéki szántóföldi mintaterek belvíz érzékenységének becslése egynemű térinformatikai eljárással. Diplomamunka, Debreceni Egyetem, Agrártudományi Centrum, Mezőgazdaságtudományi Kar, Debrecen, 1-15. 